УДК 347.6

DOI https://doi.org/10.32849/2663-5313/2021.2.05

\title{
Софія Цемко,
}

аспірантка кафедри иивільного права

Інституту права

Київського начіонального університету імені Тараса Шевченка

\section{ОСОБЛИВОСТІ ЗАХИСТУ ПРАВ ТА ІНТЕРЕСІВ ДІТЕЙ ГРОМАДЯН ІСПАНІЇ НА ТЕРИТОРІЇ УКРАЇНИ}

Стаття присвячена аналізу законодавства Украӥни щодо прав та інтересів дитини в аспекті захисту дітей громадян Іспанії та дітей громадян Іспанії, що перебувають на території України. Установлено, шо ие питання регулюється внутрішнім законодавством України, яке визначає особливості захисту прав іноземців, а також міжнародними нормативно-правовими актами, учасниками яких є обидві сторони. 3'ясовано, що права й обов'язки батьків і дітей визначаються особистим законом дитини або правом, яке має тісний зв'язок із відповідними відносинами, з урахуванням найкращих інтересів дитини. Також з'ясовано, що Україна та Королівство Іспанія, виходячи із взаємного бажання розвивати й поглиблювати дружні відносини між обома крайнами та необхідності регулювання співпрачі у сфері соціального забезпечення, уклали угоду, яка стосується в тому числі й пенсії в разі втрати годувальника, допомоги по вагітності й пологах, при народженні дитини, по догляду за дитиною, допомогу сім'ям з дітьми. Така допомога не може бути зменшена, змінена, припинена або відкладена, якщо особа, яка має право на ї отримання, проживає на території іншої Договірної Сторони, а виплати здійснюються на території иієі Договірної Сторони. Зокрема, допомога призначена однією з Договірних Сторін громадянам іншої Договірної Сторони, які проживатимуть на території третьої країни, сплачуватиметься їм першою Стороною на тих же умовах, що й громадянам своєї держави, які проживають у третій країні. Єдиним винятком є сочіальна допомога, передбачена начіональним законодавством країн-учаснииь такої угоди. При визначенні для громадян Іспанії, що перебувають на території України, права на допомогу у зв'язку з материнством, по вагітності й пологах, при народженні дитини та по догляду за дитиною, згідно з положеннями Конвениї̈, Украйною має бути враховано страховий стаж, набутий на території Іспанії. Проте за умови, що вони не перекривають один одного.

Ключові слова: законодавство України, правове регулювання, захист прав та інтересів дітей, діти-громадяни Іспанії, діти громадян Іспанії.

Постановка проблеми. Захист дітей має першочергове значення для відстоювання європейських цінностей поваги до прав людини, гідності й солідарності. При цьому особливо актуальним у світлі нещодавніх подій нині є питання законодавчого забезпечення захисту прав та інтересів дітей, які перебувають на території іноземної держави. Зокрема, питання захисту дітей громадян Іспанії та дітей громадян Іспанії, що перебувають на території України.

Аналіз літературних джерел показує, що питанню захисту прав іноземних громадян серед науковців не приділено належної уваги. Більше того, захист дітей-громадян Іспанії та дітей громадян Іспанії при цьому вченими не розглядався взагалі. Це зумовлює необхідність відповідних наукових напрацювань у вказаній сфері.
Метою статті $\epsilon$ аналіз законодавства України щодо прав та інтересів дитини в аспекті захисту дітей-громадяни Іспанії та дітей громадян Іспанії, що перебувають на території України.

Виклад основного матеріалу. Питання захисту дітей-громадян Іспанії та дітей громадян Іспанії на території України регулюються внутрішнім законодавством України, яке визначає особливості захисту прав іноземців, а також міжнародними нормативно-правовими актами, учасниками яких $є$ обидві сторони. Так, згідно з позицією вітчизняного законодавця, викладеною в Законі України «Про міжнародне приватне право» [1], зобов'язання з утримання, що виникають із сімейних відносин, крім випадків, передбачених ст. 66 цього Закону, відповідно до якої права й обов'язки батьків i дітей визначаються особистим 
законом дитини або правом, яке має тісний зв'язок із відповідними відносинами та яке є більш сприятливим для дитини, регулюються правом держави, у якій проживає особа, котра має право на утримання. При цьому, якщо особа, яка має право на утримання, не може його одержати згідно з визначеним правом, застосовується право їхнього спільного особистого закону. Разом із тим якщо особа, яка має право на утримання, не може його одержати згідно 3 правом держави, у якій проживає особа, котра має право на утримання, чи правом їхнього спільного особистого закону, то в такому випадку застосовується право держави, у якій особа, яка зобов'язана надати утримання, має місце проживання. Водночас положення ст. 66 Закону України «Про міжнародне приватне право» закріплює, що права й обов'язки батьків і дітей визначаються особистим законом дитини або правом, яке має тісний зв'язок із відповідними відносинами і яке є більш сприятливим для дитини. Окреслені законодавчі норми застосовуються й до дітей громадян Іспанії, які перебувають на території України.

Своєю чергою, Законом України «Про правовий статус іноземців та осіб без громадянства» [2] установлюється обмеження щодо застосування примусового повернення дітей-іноземців. Його сутність зводиться до того, що примусове повернення не застосовується до іноземців, які не досягли 18-річного віку [2]. Звідси випливає, що громадян Іспанії, які перебувають на території України, не можуть бути примусово повернуті до Іспанії. Зауважимо, що наведене законодавче положення повністю відповідає європейському законодавству. Маємо на увазі Директиву Європарламенту та Ради про загальні стандарти й процедури держав-членів для повернення громадян третіх країн за їх незаконного перебування 16 грудня 2008 року [3], відповідно до ст. 5 якої встановлюється, що в ході імплементації Директиви держави-члени належним чином ураховують вищі інтереси дитини, сімейне життя та стан здоров’я відповідного громадянина третьої країни, дотримуються принципу не вислання.

Водночас у ст. 4 Закону України «Про біженців та осіб, які потребують додаткового або тимчасового захисту» [4] зазначається:

«1. Україна сприяє збереженню єдності сімей біженців та осіб, які потребують додаткового захисту або яким надано тимчасовий захист.

2. Члени сім'ї особи, яку визнано біженцем в Україні або особою, яка потребує додаткового захисту або якій надано тимчасовий захист в Україні, мають право з метою возз'єднання сім'ї в'їхати на територію України і бути визнаними біженцями або особами, які потребують додаткового захисту, або отримати тимчасовий захист за відсутності умов, передбачених абзацами другим - четвертим частини 1 статті 6 та абзацами другим і третім частини 1 статті 25 цього Закону.

3. У разі якщо біженці та особи, які потребують додаткового захисту або яким надано тимчасовий захист, не зможуть надати офіційні документальні докази сімейного зв'язку з членами своєї сім'ї, беруться до уваги інші докази, які мають бути оцінені відповідно до законодавства України. Відмова у возз'єднанні сім'ї не може грунтуватися виключно на підставі відсутності документів, що підтверджують факт сімейного зв'язку.

4. Біженці та особи, які потребують додаткового захисту або яким надано тимчасовий захист, можуть з метою возз'єднання сім'ї без перешкод залишити територію України».

Права дітей громадян Іспанії, що перебувають на території України, також захищені Законом України «Про державну допомогу сім'ям 3 дітьми» [5]. Зокрема, відповідно до ч. 2 ст. 1 цього Закону, іноземці й особи без громадянства, які постійно проживають в Україні, а також особи, визнані в Україні біженцями або особами, які потребують додаткового захисту, мають право на державну допомогу на рівних засадах 3 громадянами України на умовах, передбачених цим Законом, іншими законами або міжнародними договорами України, згода на обов'язковість яких надана Верховною Радою України.

Що ж стосується міжнародних нормативно-правових актів, то передусім варто відзначити, що необхідність особливого захисту дитини передбачена в Загальній декларації прав людини, у Міжнародному пакті про громадянські й політичні права (зокрема в ст. ст. 23 і 24), у Міжнародному пакті про економічні, соціальні й культурні права (зокрема в ст. 10), Женевській декларації прав дитини 1924 року, Конвенції про права дитини від 1989 року, Декларації прав дитини, прийнятій Генеральною Асамблеєю 20 листопада 1959 року, а також у статутах і відповідних документах спеціалізованих установ і міжнародних організацій, що займаються питаннями добробуту дітей.

Крім того, Україна та Іспанія є учасниками Конвенції про стягнення аліментів за кордоном, укладеної в Нью-Йорку 20 червня 1956 року [6]. Метою цієї Конвенції є спрощення процедури стягнення аліментів, сплату яких особа (далі - позивач), яка перебуває на території однієї з Договірних Сторін, має право вимагати, від іншої особи (далі - відповідач), яка підпадає під юрисдикцію іншої Договірної Сторони. Ця мета досягається за допомогою установ 
та органів, які далі називаються Органи, що передають, і Органи, що приймають. Коли позивач перебуває на території однієї Договірної Сторони (далі - держава позивача), а відповідач підпадає під юрисдикцію іншої Договірної Сторони (далі - держава відповідача), позивач може подати заяву про стягнення аліментів з відповідача до Органу, що передає, у державі позивача [6].

Крім того, Україна та Іспанія є учасниками Гаазької конвенції про цивільноправові аспекти міжнародного викрадення дітей [7], цілями якої є:

a) забезпечення негайного повернення дітей, незаконно переміщених до будьякої з Договірних держав або утримуваних у будь-якій із Договірних держав;

б) забезпечення того, щоб права на опіку й на доступ, передбачені законодавством однієї Договірної держави, ефективно дотримувалися в інших Договірних державах.

Маємо зазначити, що положення цієї Конвенції застосовуються до будь-якої дитини, яка постійно проживає в Договірній країні, безпосередньо перед учиненням акту порушення права опіки та піклування. Проте зауважимо, що застосування Конвенції припиняється, коли дитина досягає 16 років.

Не можна оминути увагою й Конвенцію про захист дітей і співробітництво в галузі міждержавного усиновлення від 29 травня 1993 року, учасниками якої також є Україна та Іспанія. Конвенція спрямована на розв'язання таких завдань:

a) гарантування здійснення міждержавного усиновлення 3 урахуванням найкращих інтересів дитини та 3 дотриманням усіх iï основних прав, визнаних міжнародним правом;

б) створення системи співробітництва між Договірними Державами з метою забезпечення дотримання таких гарантій, отже, і запобігання крадіжці, продажу чи торгівлі дітьми;

в) забезпечення визнання в Договірних Державах усиновлень, здійснених відповідно до Конвенції [8].

Конвенція застосовується, коли дитина, що постійно проживає в одній з Договірних Держав (далі - Держава походження), переїхала, переїздить або повинна переїхати до іншої Договірної Держави (далі - Приймаюча держава) чи після її усиновлення в Державі походження подружжям чи особою, яка зазвичай проживає в Приймаючій державі, або для такого усиновлення в Приймаючій державі чи в Державі походження [8]. Отже, положення цієї Конвенції застосовуватимуться до дітей громадян Іспанії, які постійно проживають на території Королівства Іспанія та які переїхали, чи повинні переїхати на територію України, чи після її усиновлення в Іспанії подружжям або особою, що зазвичай проживає в Україні, чи з метою такого усиновлення в Україні або в Іспанії. При цьому зауважимо, що Конвенція поширюється тільки на усиновлення, які створюють постійний зв'язок між батьками та дітьми.

Вагоме значення для захисту прав дітей громадян Іспанії має двостороння Угода між Україною та Королівством Іспанія про соціальне забезпечення громадян. Так, зокрема, згідно із цим нормативно-правовим актом, Україна та Королівство Іспанія, виходячи зі взаємного бажання розвивати й поглиблювати дружні відносини між обома країнами та необхідності регулювання співпраці у сфері соціального забезпечення, уклали угоду, яка стосується в тому числі й пенсії в разі втрати годувальника, допомоги по вагітності та пологах, при народженні дитини, по догляду за дитиною, допомоги сім'ям 3 дітьми [9].

Відповідно до згаданої Угоди, така допомога не може бути зменшена, змінена, припинена або відкладена, якщо особа, яка має право на їі отримання, проживає на території іншої Договірної Сторони, а виплати здійснюються на території цієї Договірної Сторони. Зокрема, допомога призначена однією 3 Договірних Сторін громадянам іншої Договірної Сторони, які проживатимуть на території третьої країни, сплачуватиметься їм першою Стороною на тих же умовах, що й громадянам своєї держави, які проживають у третій країні. Єдиним винятком є соціальна допомога, передбачена національним законодавством країн-учасниць такої угоди.

При визначенні для громадян Іспанії, що перебувають на території України, права на допомогу у зв'язку з материнством, по вагітності та пологах, при народженні дитини та по догляду за дитиною, згідно 3 положеннями Конвенції, Україною має бути враховано страховий стаж, набутий на території Іспанії, проте за умови, що вони не перекривають один одного.

Зокрема, проблемним нині залишається питання захисту дітей громадян Іспанії, народжених сурогатними матерями в Україні. Про недостатню захищеність прав таких дітей свідчить нещодавня ситуація. Ідеться про ситуацію, за якої іспанське консульство в Києві відмовило в наданні іспанського громадянства немовлятам, які народилися за допомогою сурогатного материнства. Посольство Іспанії оголосило, що не дозволить реєструвати народження будьяких інших дітей, народжених за допомогою сурогатного материнства, що суперечить Конституції Іспанії. В Іспанії для реєстрації дитини, народженої в результаті сурогатного материнства, потрібно одержати постанову 
іспанського судді. Отже, права дітей на громадянство не гарантуються автоматично.

Законодавство Іспанії встановлює імперативну вимогу для реєстрації в Іспанії батьківства подружжя щодо дитини. Зокрема у контексті досліджуваного питання йдеться про необхідність отримання в Україні відповідного судового рішення, що підтверджує родинні відносини. Так, зокрема, аби зареєструвати в Іспанії дитину, народжену в результаті сурогатного материнства в Україні громадянам Іспанії, необхідно першочергово отримати рішення українських судів щодо спорідненості з такою дитиною шляхом подачі позову про встановлення факту родинних стосунків. Так, 6 квітня 2020 року заявники - громадяни Іспанії, звернулися до суду з заявою про встановлення факту родинних відносин між фізичними особами, а саме що дитина, яка народилася в місті Києві шляхом використання допоміжних репродуктивних технологій, є сином громадян Іспанії. Обгрунтовуючи підстави звернення до суду із цією заявою про встановлення факту родинних відносин між фізичними особами, заявники посилаються на те, що вони громадяни Королівства Іспанії, з 11 серпня 2005 по цей час перебувають у зареєстрованому шлюбі.

1 вересня 2019 року в результаті застосування допоміжних репродуктивних технологій методом сурогатного материнства в подружжя народився син, який має генетичну спорідненість із подружжям. Дитина народилася в Київському пологовому будинку. При цьому громадянка України, яка надавала послуги сурогатного материнства та народила дитину, надала свою письмову згоду, посвідчену приватним нотаріусом Київського міського нотаріального округу, на запис подружжя батьками дитини. Відповідно до тексту нотаріально посвідченої заяви сурогатної матері, вона підтверджує, що не є матір'ю дитини та не має жодних батьківських та інших прав щодо дитини, зобов'язується не чинити подружжю перешкод у реалізації їхніх батьківських прав. Також сурогатна мати зазначає в заяві, що відмовляється від будь-яких і всіх прав щодо дитини, що можуть виникати в неї в Королівстві Іспанія як в особи, яка народила дитину.

3 вересня 2019 року Солом'янським районним у місті Києві відділом державної реєстрації актів цивільного стану Головного територіального управління юстиції у місті Києві видано свідоцтво про народження, у якому подружжя записано батьками дитини, про що 3 вересня 2019 року зроблено актовий запис № 3871. Заявники посилаються на те, що країною громадянства та постійного місця проживання подружжя $є$ Королівство Іспанія. По завершенню всіх формальних процедур, пов'язаних із реєстрацією народження дитини, та оформлення паспорта для виїзду дитини за кордон подружжя має намір покинути Україну та повернутися разом із дитиною до Іспанії.

Зауважимо, що звернення із цією заявою до суду зумовлене спеціальним для Іспанії порядком реєстрації батьківства щодо дітей, народжених шляхом сурогатного материнства за кордоном. Так, згідно з Інструкцією Головного управління реєстрів і нотаріату (DGRN) від 5 жовтня 2010 року про процедуру реєстрації походження дітей, народжених у результаті сурогатної вагітності, визнана можливість запису такої дитини та встановлені критеpiї для отримання доступу до бази реєстрації актів цивільного стану Іспанії для дітей, народжених за кордоном за допомогою технік сурогатного материнства, а саме дозволено визнання закордонних судових документів, які підтверджують факт походження та народження дитини.

У 2019 році у зв'язку зі змінами в законодавстві Іспанії, що регулює сферу репродуктивних технологій і сурогатного материнства, установлено більш чіткі та жорсткі вимоги, дотримання яких є обов'язковим для реєстрації дітей, народжених за кордоном за допомогою технік сурогатного материнства, до бази реєстрації актів цивільного стану Іспанії. Відповідно до п. 2 Інструкції Головного управління реєстрів і нотаріату про оновлення режиму реєстрації батьківства осіб, народжених шляхом сурогатного материнства, від 18 лютого 2019 р. № 2367, заявки на реєстрацію в Консульському реєстрі актів цивільного стану про батьківство дітей, народжених після опублікування цього Розпорядження, не підлягають розгляду, за винятком випадків, коли існує рішення судових органів відповідної країни, яке є остаточним і вступило в законну силу [10]. Схожі справи українськими судами розглядалися й у 2019 році [11; 12].

3 огляду на вищевказане, за доцільне видається погодитися 3 Р. Майдаником щодо необхідності доповнення ст. 65 Закону України «Про міжнародне приватне право» ч. 2 а такій редакції: «2. Установлення й оскарження батьківства дитини, народженої із застосуванням сурогатного материнства, визначається особистим законом дитини на момент здійснення сурогатного материнства або одного з її батьків з урахуванням найкращих інтересів дитини» [13, с. 136]. Запропоновані зміни, безсумнівно, сприятимуть удосконаленню правового регулювання відносин сурогатного материнства з іноземним елементом, а отже, і захисту прав та інтересів 
дітей громадян Іспанії, народжених в Україні із застосуванням сурогатного материнства.

\section{Висновки}

Результати здійсненого аналізу дають змогу зробити висновок, що загалом питання захисту прав та інтересів дітей громадян Іспанії та дітей громадян Іспанії, що перебувають із тих чи інших причин на території України, урегульовано низкою нормативно-правових актів. Водночас належному захисту дітей у контексті досліджуваного питання перешкоджає недосконалість законодавчої бази та колізія внутрішнього законодавства обох країн.

Насамкінець варто зауважити, що питання регулювання захисту прав та інтересів дітей громадян Іспанії та дітей громадян Іспанії, що перебувають на території України, потребує подальшого наукового дослідження в напрямі пошуку шляхів удосконалення національного законодавства в цій сфері.

\section{Список використаних джерел:}

1. Про міжнародне приватне право : Закон України від 23.06.2005 № 2709-IV. URL: https:// zakon.rada.gov.ua/laws/show/2709-15\#Text (дата звернення: 21.02.2021).

2. Про правовий статус іноземців та осіб без громадянства : Закон України від 22.09.2011 № 3773-VI. URL: https://zakon.rada.gov.ua/ laws/ show/3773-17\#Text (дата звернення: 21.02.2021).

3. Директива № 2008/115/ЕС Европейского Парламента и Совета об общих стандартах и процедурах, подлежащих применению в государствах-членах для возврата незаконно пребывающих граждан третьих стран, Страсбург, 16 декабря 2008 года. URL: https://zakon.rada.gov.ua/laws/ show/994_944\#Text (дата звернення: 21.02.2021).
4. Про біженців та осіб, які потребують додаткового тимчасового захисту : Закон України від 08.07.2011. URL: https://zakon.rada.gov.ua/ laws/ show/3671-17\#Text (дата звернення: 21.02.2021).

5. Продержавнудопомогу сім'ямздітьми:Закон України від 21.11.1992 № 2811-XII. URL: https:// zakon.rada.gov.ua/laws/show/2811-12\#Text （дата звернення: 21.02.2021).

6. Конвенція про стягнення аліментів за кордоном від 20 червня 1956 року. URL: https:// zakon.rada.gov.ua/laws/show/995 425\#Text (дата звернення: 21.02.2021)

7. Гаазька конвенція про цивільно-правові аспекти міжнародного викрадення дітей від 25.10.1980. URL: https://zakon.rada.gov.ua/laws/ show/995 188\#Text (дата звернення: 21.02.2021).

8. Конвенція про захист дітей та співробітництво в галузі міждержавного усиновлення від 29.05.1993. URL: https://zakon.rada.gov.ua/ laws/ show/995 365\#Text (дата звернення: 21.02.2021).

9. Угода між Україною і Королівством Іспанія про соціальне забезпечення громадян. URL: https://zakon.rada.gov.ua/laws/show/724_0 05 \# Text (дата звернення: 21.02.2021).

10. Рішення Солом'янського районного суду м. Києва від 15 липня 2020 року у справі № 760/8607/20. URL: https://reyestr.court.gov.ua/ Review/91395236 (дата звернення: 25.01.2021)

11. Ухвала Солом'янського районного суду від 15 жовтня 2019 року у справі № 760/26991/19 URL: https://reyestr.court.ov.ua/Review/85197502 (дата звернення: 25.01.2021).

12. Постанова Київського апеляційного суду від 12 грудня 2019 року у справ № 760/26991/19. URL: https://reyestr.court.gov.ua/ Review/86434765 (дата звернення: 25.01.2021).

13. Майданик Р. Правове регулювання відносин сурогатного материнства 3 іноземним елементом. Імплементація кращого досвіду в Україні. Право Украӥни. 2020. № 3. С. 121-138.

Sophia Tsemko. Features of the protection of rights and interests of children having Spanish citizenship on the territory of Ukraine

The article is devoted to the analysis of the legislation of Ukraine on the rights and interests of the child in the aspect of protection of children-citizens of Spain and children of citizens of Spain who are on the territory of Ukraine. It is established that this questionregulatesis the domestic legislation of Ukraine, which determines the peculiarities of the protection of the rights of foreigners, as well as international regulations to which both parties are parties. It turned out that the rights and responsibilities of parents and children are determined by the personal law of the child or a right that is closely related to the relevant relationship and if it is more favorable to the child. It was also found that Ukraine and the Kingdom of Spain, based on mutual desire to develop and deepen friendly relations between the two countries and the need to regulate cooperation in the field of social security, concluded an agreement, including pensions in case of loss of breadwinner, maternity benefits, childbirth, child care, assistance to families with children. Such assistance may not be reduced, modified, suspended or deferred if the person entitled to receive it resides in the territory of the other Contracting Party and the payments are made in the territory of that Contracting Party. In particular, assistance granted by one of the Contracting Parties to nationals of the other Contracting Party residing in the territory of a third country shall be paid to them by the first Party on the same terms as to nationals of its own State residing in the third country. The only exception is social assistance provided by the national legislation of the countries party to such an agreement. When determining the right of Spanish citizens staying in Ukraine to maternity, maternity, childbirth and childcare benefits in accordance with the provisions of the Convention, Ukraine must take into account the length of service acquired in Spain. However, provided that they do not overlap.

Key words: legislation of Ukraine, legal regulation, protection of the rights and interests of children, children-citizens of Spain, children of citizens of Spain. 